\title{
Ground-Water Levels in the Ozark Aquifer along the Viburnum Trend, Southeastern Missouri, 2001-05
}

\section{Scientific Investigations Report 2006-5220}


Cover Photograph: Observation well VT-1 and Viburnum Mine 28 in the background, July 2006. Photographs courtesy of Michael J. Kleeschulte, U.S. Geological Survey. 


\section{Ground-Water Levels in the Ozark Aquifer along the Viburnum Trend, Southeastern Missouri, 2001-05}

By Michael J. Kleeschulte

Scientific Investigations Report 2006-5220 


\title{
U.S. Department of the Interior DIRK KEMPTHORNE, Secretary
}

\author{
U.S. Geological Survey \\ P. Patrick Leahy, Acting Director
}

\section{U.S. Geological Survey, Reston, Virginia: 2006}

For sale by U.S. Geological Survey, Information Services

Box 25286, Denver Federal Center

Denver, CO 80225

For more information about the USGS and its products:

Telephone: 1-888-ASK-USGS

World Wide Web: http://www.usgs.gov/

Any use of trade, product, or firm names in this publication is for descriptive purposes only and does not imply endorsement by the U.S. Government.

Although this report is in the public domain, permission must be secured from the individual copyright owners to reproduce any copyrighted materials contained within this report. 


\section{CONTENTS}

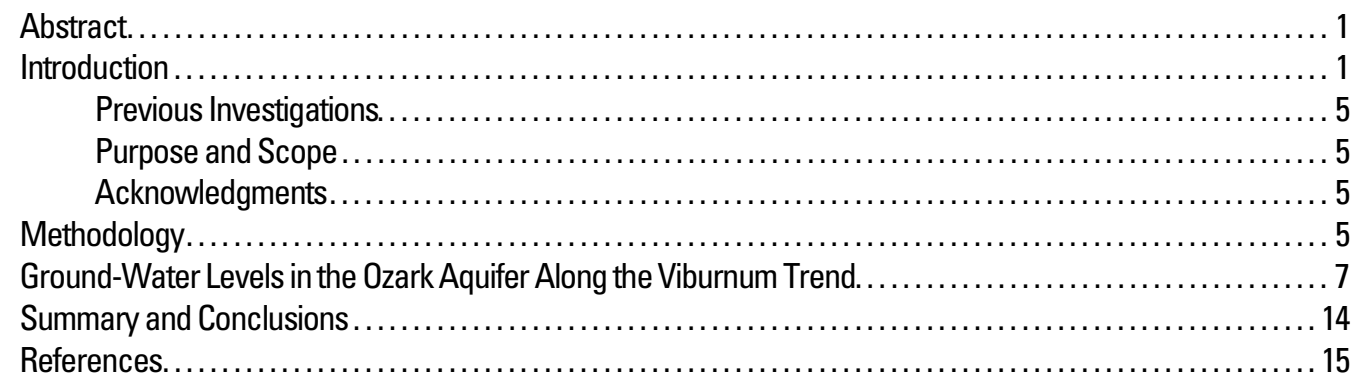

\section{Figures}

1. Map showing location of the Viburnum Trend and study area. $\ldots \ldots \ldots \ldots \ldots \ldots \ldots \ldots \ldots \ldots \ldots \ldots \ldots \ldots \ldots \ldots \ldots \ldots$

2. Stratigraphic column for an exploration hole in Reynolds County, Missouri, and a general litholgic description of formations in the Viburnum Trend. .................................

3. Geohydrologic section from southeastern Crawford County along the Viburnum Trend to west-

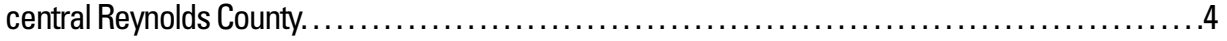

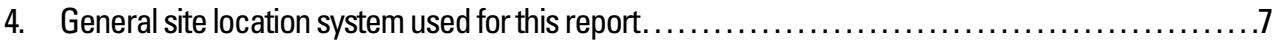

5-7. Graphs showing:

5. Monthly and cumulative departure from normal precipitation for the East Ozarks

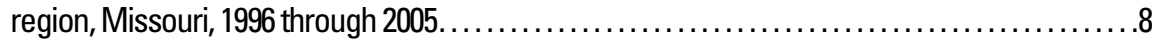

6. Daily mean depth-to-water for monitoring wells along the Viburnum Trend and daily precipitation in Salem, Missouri, 2002 through $2005 \ldots \ldots \ldots \ldots \ldots \ldots \ldots \ldots \ldots \ldots \ldots . . . . \ldots$

7. Difference between daily mean water levels, monthly precipitation, and cumulative monthly precipitation at wells VT-1 and VT-8, 2002 through $2005 \ldots \ldots \ldots \ldots \ldots 13$

8. Schematic diagram of well VT-1, well VT-8, and climatological station locations .............. 14

\section{Tables}

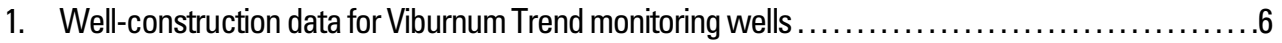

2. Manually measured water levels in Viburnum Trend monitoring wells, 2001 through 2005 ....... 19

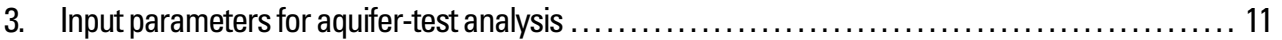




\section{Conversion Factors and Datum}

\begin{tabular}{|c|c|c|}
\hline Multiply & By & To obtain \\
\hline \multicolumn{3}{|c|}{ Length } \\
\hline inch (in.) & 25.4 & millimeter (mm) \\
\hline foot $(\mathrm{ft})$ & 0.3048 & meter $(\mathrm{m})$ \\
\hline mile (mi) & 1.609 & kilometer (km) \\
\hline \multicolumn{3}{|c|}{ Area } \\
\hline square foot $\left(\mathrm{ft}^{2}\right)$ & 0.09294 & square meter $\left(\mathrm{m}^{2}\right)$ \\
\hline \multicolumn{3}{|c|}{ Volume } \\
\hline gallon (gal) & 3.785 & liter $(\mathrm{L})$ \\
\hline million gallons (Mgal) & 3,785 & cubic meter $\left(\mathrm{m}^{3}\right)$ \\
\hline cubic foot $\left(\mathrm{ft}^{3}\right)$ & 0.02832 & cubic meter $\left(\mathrm{m}^{3}\right)$ \\
\hline \multicolumn{3}{|c|}{ Flow rate } \\
\hline cubic foot per second $\left(\mathrm{ft}^{3} / \mathrm{s}\right)$ & 0.02832 & cubic meter per second $\left(\mathrm{m}^{3} / \mathrm{s}\right)$ \\
\hline gallon per minute (gal/min) & 0.06309 & liter per second $(\mathrm{L} / \mathrm{s})$ \\
\hline million gallons per day $(\mathrm{Mgal} / \mathrm{d})$ & 0.04381 & cubic meter per second $\left(\mathrm{m}^{3} / \mathrm{s}\right)$ \\
\hline \multicolumn{3}{|c|}{ Transmissivity* } \\
\hline foot squared per second $\left(\mathrm{ft}^{2} / \mathrm{s}\right)$ & 0.0929 & meter squared per second $\left(\mathrm{m}^{2} / \mathrm{s}\right)$ \\
\hline
\end{tabular}

Vertical coordinate information is referenced to the National Geodetic Vertical Datum of 1929 (NGVD 29). Altitude, as used in the report, refers to distance above or below NGVD 29. NGVD 29 can be converted to the North American Vertical Datum of 1988 (NAVD 88) by using the National Geodetic Survey conversion utility available at URL http://www.ngs.noaa.gov/TOOLS/Vertcon/vertcon.html.

Horizontal coordinate information is referenced to the Datum of 1927 (NAD 27).

*Transmissivity: The standard unit for transmissivity is cubic foot per day per square foot times foot of aquifer thickness $\left[\left(\mathrm{ft}^{3} / \mathrm{d}\right) / \mathrm{ft}^{2}\right] \mathrm{ft}$. In this report, the mathematically reduced form, foot squared per second $\left(\mathrm{ft}^{2} / \mathrm{s}\right)$, is used for convenience. 


\title{
Ground-Water Levels in the Ozark Aquifer along the Viburnum Trend, Southeastern Missouri, 2001-05
}

\author{
by Michael J. Kleeschulte
}

Abstract

During 2001, eight monitoring wells were installed along the Viburnum Trend to determine if dewatering of lead-zinc mines in the St. Francois aquifer affected water levels in the surficial Ozark aquifer. The well locations were chosen specifically to investigate the effects of different mining scenarios. Before data collection, much of southern Missouri, including the Viburnum Trend area, experienced a drought that began in late 1999. Dry conditions existed in the area until early 2002, about the time data recorders were installed in the monitoring wells.

The water-level data indicate no long-term, continuous water-level declines occurred from 2002 to 2005 at five monitoring wells (VT-2, VT-3, VT-5, VT-6, and VT-7), four of which are over active mining areas. Conversely, these five wells had increasing water levels with time. Another well (VT-4) placed over an active mining area, did have a long-term waterlevel decline (about 30 foot) that developed during the study. On a local scale, the water-level data from this well reinforces conclusions of previous investigations that report small areas of drawdown in the Ozark aquifer may be present along the Viburnum Trend as the result of mine dewatering.

A monitoring well (VT-1) installed over an abandoned mine where flooding is occurring showed an increasing waterlevel trend. Another well (VT-8) installed in an area where mining was expected to occur after well installation showed a lowering ground-water trough in 2004 and 2005. Comparing monthly precipitation and daily mean water-levels differences at these two wells indicates that for most of the period from 2002 to 2005 , the converging water-level difference that occurred can be explained by local precipitation differences rather than being mining induced. Local precipitation differences, however, do not explain the 15-foot decrease in waterlevel difference that was observed during the period January through June 2004.

\section{Introduction}

The initial discovery of lead-zinc deposits near Viburnum, Missouri (fig. 1), was made in 1955 and ore production began in the mid-1960s (Wharton, 1975). Between 1960 and 1973, eight underground operating mines opened (Warner and others,
1974) along a 30-mile, north-south trending zone that can have minable ore hundreds of feet wide or wider. Currently (2006), some of the original mines have been shut down, other mines have opened, and several of the mines have been connected underground. This entire mining area is referred to locally as the Viburnum Trend (fig. 1).

Predominantly carbonate rock sequences of the Ordovician Canadian Series and Upper Cambrian Series (Roubidoux Formation to the base of the Lamotte Sandstone) overlie granites and rhyolites of the Precambrian basement rock (fig. 2). Locally, the Roubidoux Formation is present and exposed on some of the highest ridge tops, but generally the formations from the Gasconade Dolomite to the Potosi Dolomite crop out (Middendorf and others, 2003). The rocks from the Roubidoux Formation to the base of the Potosi Dolomite form the surficial Ozark aquifer, the primary source of water for private- and public-water supplies and major springs in southern Missouri. Formations of the Ozark aquifer typically were not logged or cored by mining companies during exploration drilling and, therefore, could not be defined on the geohydrologic section shown in figure 3. The St. Francois confining unit underlies the Ozark aquifer and consists of dense carbonates and shales of the DerbyDoerun Dolomite and Davis Formation. Regionally, the physical and hydraulic characteristics of the confining unit generally impede the movement of ground water between the overlying Ozark aquifer and the underlying St. Francois aquifer (Imes and Emmett, 1994). The carbonate (dolostone and limestone) and sandstone St. Francois aquifer consists of the Bonneterre Formation and the underlying Lamotte Sandstone. The Bonneterre Formation is the host formation for the largest and most important lead-zinc deposits in southeastern Missouri (Wharton, 1975). Other than the city of Viburnum (fig. 1), which uses water from an abandoned mine as a drinking-water source, the St. Francois aquifer usually is not used along the Viburnum Trend because the shallower Ozark aquifer adequately meets the drinking water needs of the region.

Dewatering of the St. Francois aquifer is the result of drainage of ground water into mined areas and pumpage of this water to the surface. Typical pumpage from the St. Francois aquifer for mine dewatering in the Viburnum Trend is estimated to range from 25 to 27 million gallons per day (Warner and others, 1974; Denis N. Murphy, The Doe Run Company, written commun., 2000 and 2004). This pumpage rate has been occurring for most of the more than 40 years the mines have been in operation. 


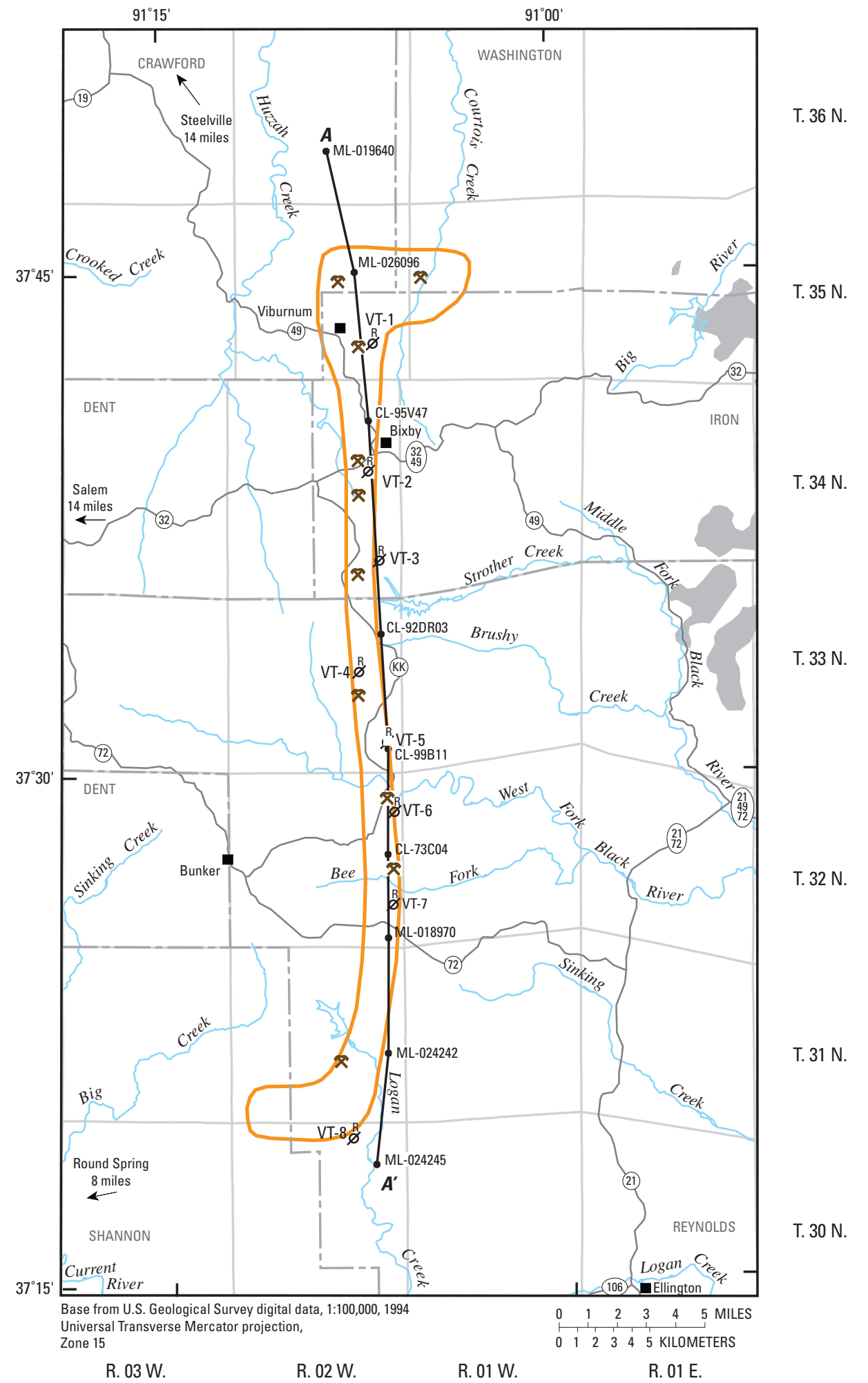

\section{EXPLANATION}

St. Francois Mountains Precambrian rock outcrop area

ML-024245 Generalized trace of section, borehole

$\boldsymbol{A} \longrightarrow \boldsymbol{A}^{\prime} \quad$ locations used to draw section, and

identifier (section shown in fig. 3)
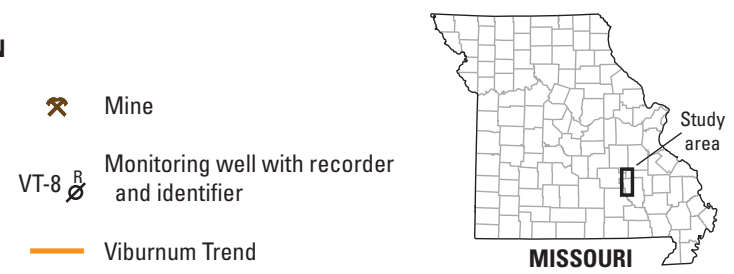

Figure 1. Location of the Viburnum Trend and study area. 


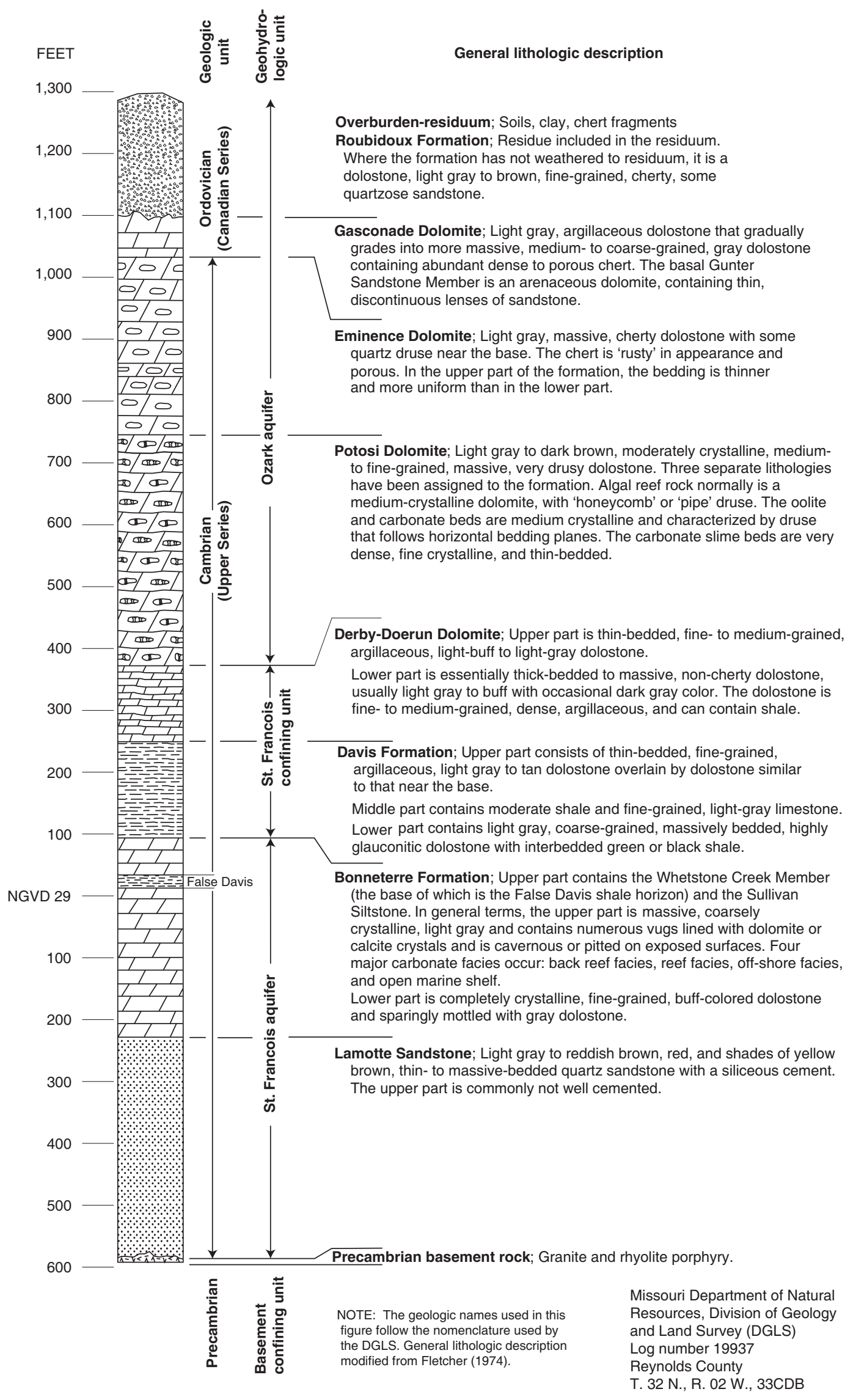

Figure 2. Stratigraphic column for an exploration hole in Reynolds County, Missouri, and a general lithologic description of formations in the Viburnum Trend. 


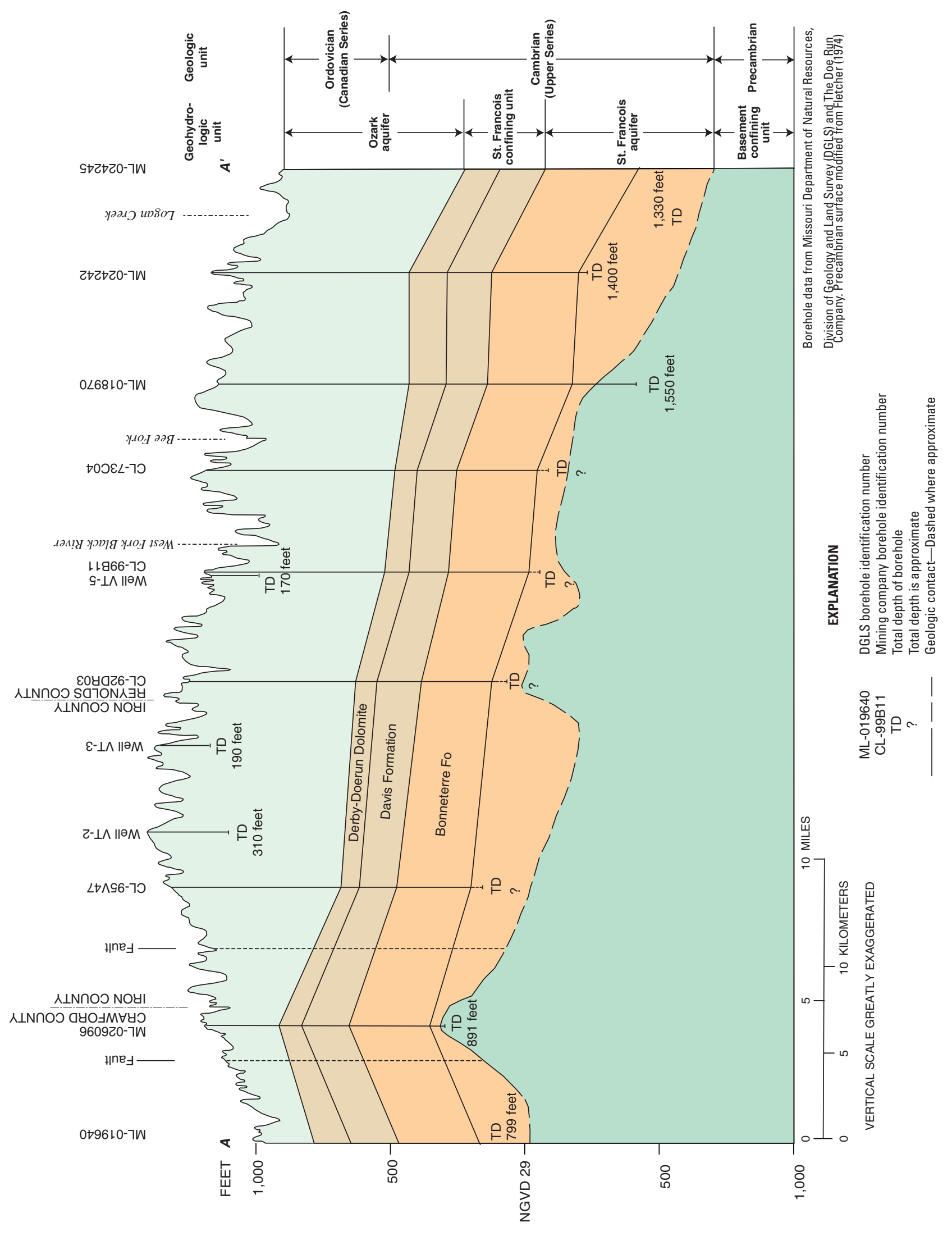

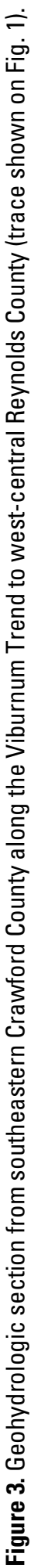




\section{Previous Investigations}

Previous investigations have been conducted to investigate whether or not continued pumpage from the St. Francois aquifer (mine dewatering) has affected water levels in the overlying Ozark aquifer. In 1974, the University of Missouri - Rolla completed a study that analyzed the pumping effects on the St. Francois aquifer and the Ozark aquifer (Warner and others, 1974). Water-level data were collected from 20 observation wells in the St. Francois aquifer in the vicinity of 5 active mines, and from 9 observation wells in the Ozark aquifer that were around the southern-most mine. This study concluded that depending on the mine location, the potentiometric surface of the St. Francois aquifer declined 600 to 1,200 feet as a result of mine dewatering. The aquifer thickness typically ranges from 300 to 600 feet, but because the aquifer is confined, the potentiometric surface extends much higher than the top of the aquifer. During mine dewatering, the pressure head is lowered first. After the potentiometric surface has declined below the top of the aquifer, the aquifer will begin to be dewatered. The report also concluded that the effect of pumping in the St. Francois aquifer probably is not great beyond a distance of about 5 miles from any of the mines, and that the areas of major effect are more restricted than the stated 5-mile distance. The report also stated that as mining continues, the affected area is not expected to widen much from east to west, but as the mines become interconnected, a continuous narrow dewatered zone throughout the length of the Viburnum Trend in the St. Francois aquifer is expected. The report also concluded that water-level changes in the surficial Ozark aquifer were not large (Warner and others, 1974). The small water-level declines in the Ozark aquifer are a result of the effective confining capability of the formations overlying the St. Francois aquifer in the area, specifically the St. Francois confining unit (figs. 2 and 3 ).

Another study that investigated the drawdown effects of mine dewatering on the Ozark aquifer was conducted in 1999 by the U.S. Geological Survey (Kleeschulte, 2001). A pre-mining (before 1960) potentiometric surface was drawn for the Ozark aquifer using 118 historic water-level measurements reported by well drillers to the Missouri Department of Natural Resources when these wells were drilled. This pre-mining potentiometric surface was compared digitally to a potentiometric surface drawn for the Ozark aquifer from 66 water levels measured in 1999 from monitoring, domestic, and public-supply wells along the Viburnum Trend. The general conclusion was that no large cones of depression were apparent in the potentiometric surface of the Ozark aquifer along the Viburnum Trend as a consequence of mining activity. Some localized leakage of water from the Ozark aquifer into the St. Francois aquifer probably is occurring at ventilation shafts and inadequately plugged exploration boreholes; therefore, small areas of measurable drawdown may exist (Warner and others, 1974; Miller and Vandike, 1997; Kleeschulte, 2001).

Much of the Viburnum Trend occurs under the sparsely populated Mark Twain National Forest. The area includes scattered parcels of private property that contain isolated home- steads or small communities, with most of the private property being concentrated along major roads or along stream valleys. Consequently, there is not an adequate spatial distribution of wells directly over active mines along the Viburnum Trend for water-level measurements. This was the situation during the two previous studies (Warner and others, 1974; Kleeschulte, 2001); therefore, the locations where water-level measurements in the Ozark aquifer were needed most corresponded to areas where the aquifer was least accessible. Because of this, it was decided to drill monitoring wells directly over active mining areas along the Viburnum Trend, and to continually monitor water levels to better assess possible water-level declines in the Ozark aquifer. Through the cooperation of the U.S. Department of Agriculture, Forest Service (Forest Service) and The Doe Run Company, locations of possible well sites on properties managed by these entities were determined and access to areas meeting these criteria were approved; subsequently, eight monitoring wells were installed during the fall of 2001 for waterlevel monitoring by the U.S. Geological Survey.

\section{Purpose and Scope}

This report describes water-level data in the surficial Ozark aquifer collected from October 2001 through December 2005 from eight monitoring wells located along the Viburnum Trend. The data were collected to evaluate the effects of ground-water discharge, primarily from mine dewatering in the deeper St. Francois aquifer, on the water levels in the Ozark aquifer. The monitoring wells constructed for this study are distributed in a generally linear pattern about 27 miles long from north to south (fig. 1).

\section{Acknowledgments}

Gratitude is expressed to The Doe Run Company for allowing access to mine maps during the monitoring well site location process and for allowing monitoring well installations to occur on their property. Special recognition is extended to Joe Wagner (Chief Geologist, The Doe Run Company) for his assistance and cooperation during the site location process and Denis Murphy (Safety and Environmental Manager, The Doe Run Company) for gathering information on the status of mining beneath the monitoring wells. Gratitude also is expressed to the Forest Service for allowing well installations on the Mark Twain National Forest, with a special recognition to Sarah Bradley (Wildlife Biologist, Forest Service) who provided oversight during the drilling in the National Forest.

\section{Methodology}

Even though the eight monitoring wells are distributed along almost the entire length of the Viburnum Trend, it is recognized that the water-level data from each well represents only 
the local ground-water conditions in the Ozark aquifer in the vicinity of the well. To monitor the Ozark aquifer along the entire Viburnum Trend would require many more wells. However, it is assumed the water-level data from these eight selected sites would be adequate to detect continued, large-scale regional drawdown in the Ozark aquifer along the Viburnum Trend if it were occurring.

The monitoring well locations were chosen specifically to represent the various possible mining scenarios. Well VT-1 was installed over a mine that was scheduled to be shut down after the well was installed. Data from well VT-1 would monitor water levels in the Ozark aquifer during the period of rising water levels in the St. Francois aquifer after mine closure. Mining ceased and the pumps were removed from the mine in August 2004, allowing the mine to flood (Denis N. Murphy, The Doe Run Company, written commun., 2004). Wells VT-5 and VT- 8 were installed above unmined areas but where mine workings were progressing toward at the time of well installation. These sites would be used to monitor baseline water levels in the Ozark aquifer and monitor the effects of mine dewatering on the Ozark aquifer as mining begins in an area. The remaining five wells (VT-2,VT-3, VT-4, VT-6, and VT-7) were placed directly over active mining areas where dewatering had been occurring for an extended time.

The eight monitoring wells were drilled from October through December 2001. To expedite the Forest Service special use permitting process, well sites were chosen that were of adequate size and void of trees. Because of existing modifications to the land surface, wells VT-3, VT-4, and VT-8 are believed to occupy former lead-zinc exploration drilling sites that had boreholes that were plugged and abandoned years earlier. Typically, the monitoring wells were installed by air rotary drilling to less than 100 feet below the top of the water table. Six-inch steel surface casing was installed in all wells to a minimum depth of 80 feet below land surface to prevent the borehole walls from caving and to prevent surface drainage from entering the well (table
1). In several wells, more casing was required so that the bottom of the casing could be set in solid rock. Wells were open hole from the bottom of the surface casing to total depth. The wells were instrumented in February 2002 with transducers that measure and record water-levels at 1-hour intervals.

Well locations are described by latitude and longitude coordinates and by the General Land Office coordinate system. Using this coordinate system (fig. 4), the first three sets of numbers representing a borehole location designate township, range, and section. The letters that follow indicate quarter section, quarter-quarter section, and quarter-quarter-quarter section. The quarter sections are represented by letters A, B, C, and $\mathrm{D}$ in counterclockwise order, starting in the northeastern quadrant. The altitude of land surface was determined from 7.5minute U.S. Geological Survey topographic maps. Because of the steep topography of the area, the topographic maps have a contour interval of 20 feet, with an accuracy of plus or minus 0.5 the contour interval (plus or minus 10 feet).

During each site visit, manual water-level measurements were made at each monitoring well. The measurements were read to the nearest 0.01 foot using a calibrated electric tape and referenced to land surface (table 2, at the back of the report). When possible, the same electric tape was used at each well to measure water levels. The manual water-level measurements are considered the standard and were used to verify the accuracy of the transducer measurements, which were adjusted as necessary.

All eight monitoring wells were originally equipped with water-level recorders that were custom-length, electronic pressure transducers, vented to atmospheric pressure. The daily mean water level was computed from continual hourly waterlevel measurements obtained from the pressure transducers. Unless otherwise stated, it is believed that the reported transducer water level is accurate to within 0.05 foot of the actual water level in the well. Instrument drift corrections to the recorded data were occasionally required when the transducer

Table 1. Well-construction data for Viburnum Trend monitoring wells.

[Units for latitude and longitude are in North American Datum of 1927; DDMMSS, degrees, minutes, seconds; MM-DD-YYYY, month, day, year; units for altitudes are in feet above National Geodetic Vertical Datum of 1929.]

\begin{tabular}{ccccccccc}
\hline Well & $\begin{array}{c}\text { Latitude } \\
\text { name }\end{array}$ & $\begin{array}{c}\text { Longitude } \\
\text { (DDMMSS) }\end{array}$ & $\begin{array}{c}\text { General land office } \\
\text { (DDMMSS) }\end{array}$ & $\begin{array}{c}\text { coordinates } \\
\text { Date of } \\
\text { construction } \\
\text { (MM-DD-YYYY) }\end{array}$ & $\begin{array}{c}\text { Altitude of } \\
\text { land } \\
\text { surface } \\
\text { (feet) }\end{array}$ & $\begin{array}{c}\text { Height of } \\
\text { measuring } \\
\text { point } \\
\text { (feet) }\end{array}$ & $\begin{array}{c}\text { Depth of } \\
\text { well } \\
\text { (feet) }\end{array}$ & $\begin{array}{c}\text { Bottom of } \\
\text { casing } \\
\text { (feet) }\end{array}$ \\
\hline Well VT-1 & 374252 & 0910654 & T35N R02W 26DBB & $12-10-2001$ & 1,140 & 2.4 & 110 & 80 \\
Well VT-2 & 373905 & 0910710 & T34N R02W 11DAA & $12-11-2001$ & 1,420 & 2.1 & 310 & 120 \\
Well VT-3 & 373628 & 0910648 & T34N R02W 25CAC & $12-10-2001$ & 1,360 & 2.0 & 190 & 80 \\
Well VT-4 & 373307 & 0910740 & T33N R02W 14ACC & $12-04-2001$ & 1,410 & 2.2 & 390 & 190 \\
Well VT-5 & 373056 & 0910638 & T33N R02W 25CDD & $12-03-2001$ & 1,160 & 2.1 & 170 & 126 \\
Well VT-6 & 372853 & 0910618 & T32N R02W 12ADB & $11-05-2001$ & 1,150 & 3.2 & 250 & 210 \\
Well VT-7 & 372608 & 0910633 & T32N R02W 25ACD & $10-31-2001$ & 1,165 & 2.2 & 275 & 250 \\
Well VT-8 & 371910 & 0910811 & T30N R02W 02CBA & $11-05-2001$ & 990 & 2.1 & 110 & 80 \\
\hline
\end{tabular}




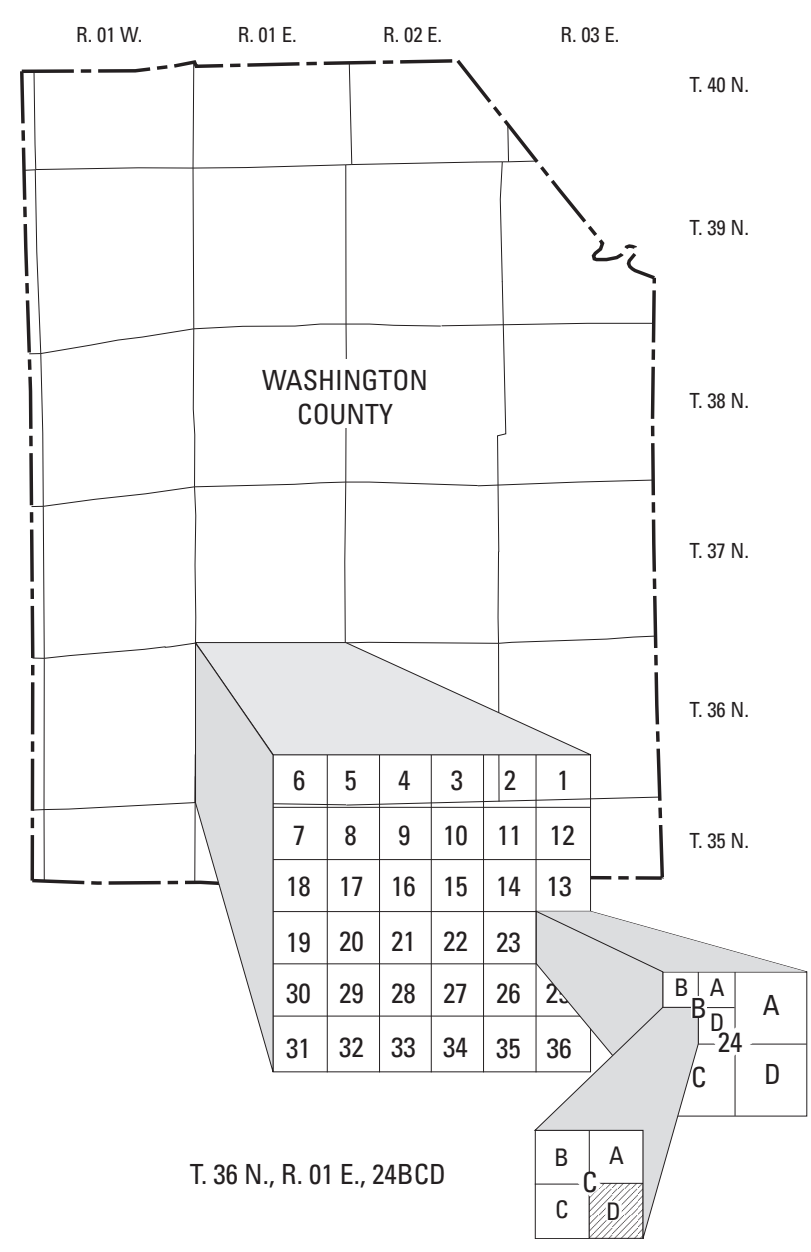

Figure 4. General site location system used for this report

measurement and the field water-level measurement had a discrepancy of more than the reporting accuracy of 0.05 foot.

Daily water-level values for each well are given in the Missouri Water Science Center annual data report for the corresponding water years 2002 to 2005 (Hauck and Nagel, 2003, 2004, 2005; Hauck and Harris, 2006). Several wells have extended period of missing record caused by equipment or power failures. Well VT-4 had missing record caused by waterlevel declines that began during January 2003. By February 2003 , water levels in the well dropped below the level of the transducer. Attempts were made to lower the transducer to keep it below the water surface, but the design of the transducer would not permit this modification of its intended use for an extended period of time. In June 2003, that transducer was replaced with a transducer that was not vented to atmospheric pressure. This resulted in the water-level data that were collected from June 2003 until September 2004 being less accurate than the data from the vented transducers, and is assumed to be plus or minus 1-foot. In May 2005, the vented pressure transducer in well VT2 malfunctioned and could not be repaired. This transducer was also replaced with an unvented one. The water-level data accuracy collected from unvented transducers after September 2004 was improved by barometric pressure compensation.

\section{Ground-Water Levels in the Ozark Aquifer along the Viburnum Trend}

Much of southern Missouri, including the Viburnum Trend area, experienced a drought that began in late 1999 (University of Missouri-Columbia, 2006) about 2 years before the well installations. Monthly and cumulative departure from normal precipitation from 1996 through 2005 for the East Ozarks region of Missouri, which includes the Viburnum Trend [National Oceanic and Atmospheric Administration (NOAA), 1996-2005] are shown in figure 5. From 1997 through early 1999 , there was an excess of precipitation when compared to normal monthly amounts. In the summer of 1999, a period of less than normal precipitation began and continued into 2002 . This dry period culminated during the spring and summer of 2001, when the cumulative precipitation since 1996 was more than 11 inches below normal (fig. 5B). The water-level recorders were installed in the monitoring network wells during February 2002, which typically is early in the recharge period of the annual water-level fluctuation cycle (fig. 6). The combination of the drought and subsequent dry conditions and the time of year the continual water-level data collection began, created a situation where the initial water-level data were abnormally low. The dry conditions abated during the winter and spring of 2002 (fig. 5B), and water levels rose in all eight monitoring wells into the early summer of 2002 (fig. 6).

Hydrograph data representing all eight wells for the period of record show the two shallowest wells (wells VT-1 and VT-8; table 1 and fig. 6A) have water levels less than 100 feet below land surface and are the most responsive to precipitation events. The hydrograph data for these two wells are plotted with the daily precipitation totals reported by the NOAA climatological station at Salem, Missouri. Depending on antecedent conditions, a precipitation event of 1-inch or more generally caused both wells to respond almost immediately with water-level increases. The water-level increase in well VT-8 typically is larger compared to well VT- 1 and peaks several days earlier. Occasionally, however, the overall water-level increase is greater in well VT-1 than in well VT-8. Because these two wells are about 27 miles apart and represent the northernmost and southernmost wells, this discrepancy may be more a function of differences in precipitation at each well, rather than differences in geohydrologic conditions at the wells.

Unlike the two shallowest wells, the response to individual precipitation events in the middle groups of wells (VT-3, VT-5, VT-6, VT-7, and VT-2; fig. 6B and C), where the depth to water is more than 100 feet below land surface, is more subdued or non-existent. The hydrographs for these wells show the observed water-level changes primarily were seasonal fluctuations. The low initial water levels for these wells are assumed to be a result of the prior drought and subsequent dry conditions. Manual water-level measurements were being made in all wells of the monitoring well network a couple of months before the transducers were installed (table 2). For the middle groups of wells, the lowest measured water levels occurred before trans- 

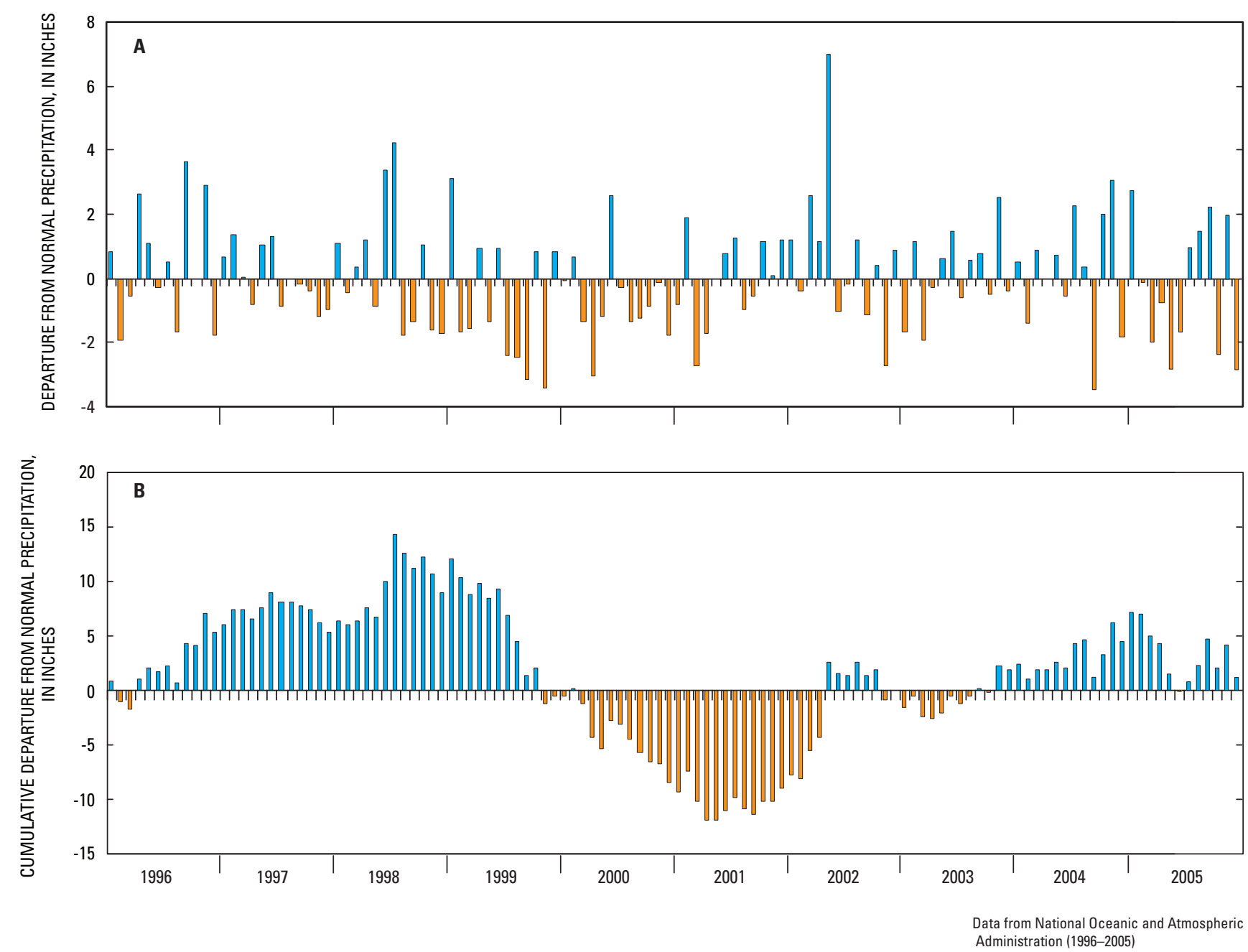

Figure 5. Monthly (A) and cumulative (B) departure from normal precipitation for the East Ozarks region, Missouri, 1996 through 2005.

ducer installation or within a few weeks after the transducers were installed. This is in contrast to the shallow wells (VT-1 and VT-8), where the initial water-level measurements were not among the lowest during the study. Water levels in the middle group of wells continued to recover during the winter and spring of 2002, and the resulting water levels are considered to be more representative of normal hydrologic conditions. The annual water-level declines that normally occur each fall into winter (trough) for this set of wells did not fall below the initial conditions throughout the remainder of the study, and generally the altitude of the trough rose each succeeding year and water levels increased with time. An evaluation of the seasonal peaks also indicated no continuous water-level declines occurred during the study. Based on these observations, it is concluded no long-term, continuous water-level declines occurred from 2002 to 2005 at wells VT-2, VT-3, VT-5, VT-6, or VT-7. All these wells, except VT-5, were placed over active mining areas.
Well VT-4, the deepest of the monitoring wells with a total depth of 390 feet below land surface (fig. 1 and table 1), is located over an active mining area near the middle of the Viburnum Trend. The well penetrates the Gasconade and Eminence Dolomites, and possibly the top of the Potosi Dolomite. The bottom of the well is about 400 feet above the top of the DerbyDoerun Dolomite of the St. Francis confining unit. The hydrograph from monitoring well VT-4 was unique (fig. 6D) in that it is the only well in the network that had a long-term waterlevel decline that did not recover. On a local scale, the waterlevel data from this well reinforces conclusions of previous investigations that report small areas of drawdown in the Ozark aquifer may be present along the Viburnum Trend as a result of mine dewatering.

During the summer and fall of 2002, the water-level fluctuation for well VT-4 was not synchronous with the other seven wells. Whereas water levels in the other monitoring wells 

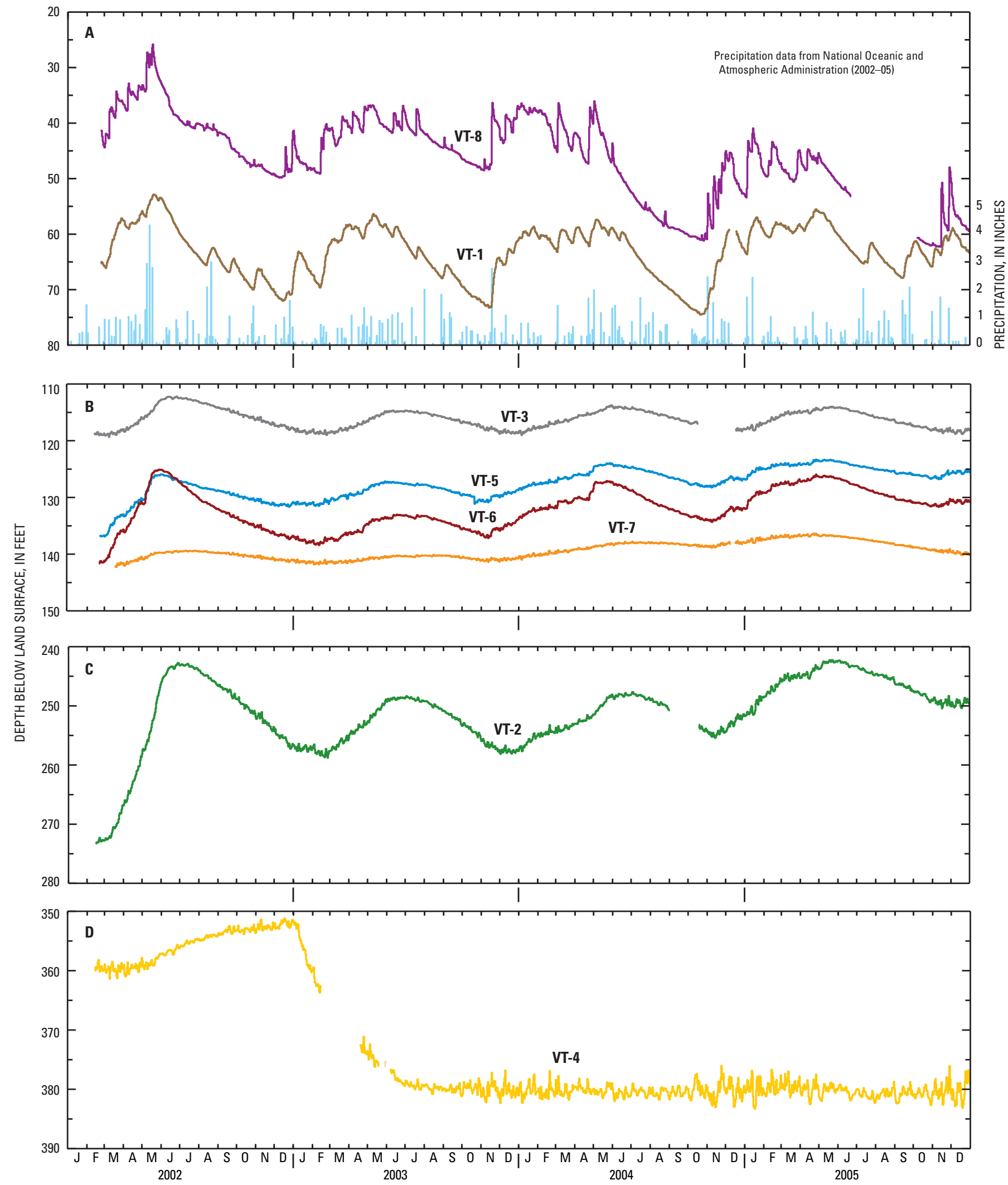

Figure 6. Daily mean depth-to-water for monitoring wells along the Viburnum Trend (A-D) and daily precipitation in Salem, Missouri (A), 2002 through 2005. 
started decreasing in June and July 2002, water levels in well VT-4 continued to increase into January 2003. Either the water level in well VT-4 was still recovering from the prior prolonged dry conditions, or the observed water-level response was the result of factors other than localized precipitation or normal seasonal responses.

The most prominent feature of the well VT-4 hydrograph is the water-level decline of about 30 foot, that began in January 2003. This occurred 6 to 7 months after the other seven wells appeared to have recovered from the prior prolonged dry conditions, and 11 months after the transducer and data recorder were installed in the well. It is unknown what may have occurred to initiate the water-level decline observed in the well in January 2003 , but equilibrium between recharge and withdrawal was not reached until July 2003, when the water level stabilized. Possible explanations for the drawdown observed at well VT-4 are a decrease in recharge, an increase in withdrawal from the aquifer, or a change in the hydraulic characteristics of the aquifer or underlying confining unit allowing more water to flow from the aquifer. Because precipitation amounts had returned to normal levels by summer 2002, and there are no known domestic or public-water supply wells in the area, the lack of recharge or additional well pumpage do not appear to be the cause for the water-level decline. Increased flow to area springs that have the monitoring well in their recharge area is a possibility, but this would not be possible to verify because no historic or recent spring data have been collected in this remote area. A more plausible explanation for the water-level decline is a change in subsurface hydraulic characteristics of the Ozark aquifer or the underlying St. Francois confining unit in the vicinity of the well, which would allow additional ground-water flow, either diffuse or discrete, to occur from the Ozark aquifer.

Two potential pathways exist in the vicinity of well VT-4 for discrete ground-water flow to occur out of the Ozark aquifer and into the St. Francois aquifer. It is probable that well VT-4 occupies the site of an old exploration borehole that was plugged and abandoned years earlier. Also, a mine ventilation shaft that was installed years before the monitoring well was drilled (Sarah Bradley, Forest Service, oral commun., 2005) is present about 775 feet northeast of the well. It is hypothesized that water may be moving from the Ozark aquifer into the mine workings in the St. Francois aquifer through either the former exploration borehole that was plugged and abandoned, or through the nearby mine ventilation shaft. The mining company was contacted and informed of the situation and they reported no abnormal inflow of water into the mine in the vicinity of well VT-4 (Bob Dunn, The Doe Run Company, oral commun., 2003).

Well VT-4 is not the only well in the monitoring network that occupies a former exploration drill site or has a nearby ventilation shaft. A conscious effort was made to avoid locating monitoring wells near these types of structures during the well site selection process. However, it was not possible to totally avoid this situation, especially in the areas where active mining was occurring. Consequently, wells VT-3 and VT- 8 are probably on former exploration drill sites, and wells VT-2 and VT-6 are within 1,000 feet of ventilation shafts; however, water levels in these wells show no indication of being affected by these nearby auxiliary structures.

The hypothesis of downward ground-water leakage from the Ozark aquifer into the St. Francois aquifer through the exploration borehole or the nearby ventilation shaft resulting in localized areas of drawdown, is consistent with the conclusions of an incident reported by Miller and Vandike (1997). Their report states a large diameter ventilation shaft (vent shaft 50) that was drilled about 1,000 feet northwest of the village of Bixby (fig. 1), in the northern part of the Viburnum Trend, was determined to be leaking. These shafts are normally cased only through the surficial materials and produce small quantities of water. Vent shaft 50 encountered well-developed, solution enlarged openings in the Potosi Dolomite. Initially, inflow into the underlying mine (1,000 feet below land surface) was several hundred gallons per minute. This inflow did not interfere with mining operations and was pumped back to the surface. The inflow into the mine, however, resulted in substantial waterlevel declines in the Ozark aquifer around Bixby. Most of the domestic wells in the area were less than 200 feet deep and produced from a permeable zone in the Eminence Dolomite at a depth of about 150 feet. The permeable zone was dewatered by the shaft, and most of the domestic wells, though not dry, would no longer sustain yields of more than 3 gallons per minute. The mining company grouted the bedrock around the shaft reducing the volume of water draining into the mine to 50 to 70 gallons per minute. The shaft was plugged in September 1991, after it was no longer needed. Almost immediately water levels in the Ozark aquifer began recovering in the area, and recovery of water levels to pre-vent shaft 50 conditions took about 3.5 years (Miller and Vandike, 1997).

A cursory aquifer-test analysis using the Theis solution (Freeze and Cherry, 1979) for unconfined aquifers was performed on the drawdown data collected from well VT-4 to estimate the discharge rate needed to achieve the observed drawdown. In the analysis, well VT-4 represented the observation well, and the ventilation shaft and exploration borehole were each used in separate simulations to represent a pumping well, although both more closely resemble drains. Many of the input parameters needed for the analysis were known, others had to be estimated (table 3). The thickness of the Ozark aquifer was calculated from available well logs in the area and assigned a saturated thickness of 450 feet. The observation well (VT-4) opening is the interval from the bottom of the well casing to the bottom of the well (190 to 390 feet). In the ventilation shaft scenario, the distance from the observation well to the pumping well (ventilation shaft) was measured from air photos to be 775 feet. In the borehole scenario, the distance was estimated to be 40 feet. Because ventilation shafts typically are cased only through the surficial material, and because the exploration borehole plug in the St. Francois confining unit is assumed to have failed for this scenario, both are considered to fully penetrate the Ozark aquifer and continue into the St. Francois aquifer. The casing and effective well radius of the ventilation shaft and exploration borehole were assumed to be 2.0 and 0.25 feet, respectively. The aquifer was considered to be unconfined and isotropic. 
Table 3. Input parameters for aquifer-test analysis.

[ft, foot; $\mathrm{ft}^{2} / \mathrm{s}$, squared foot per second; $\mathrm{ft}^{3} / \mathrm{s}$, cubic foot per second]

\begin{tabular}{lll}
\multicolumn{1}{c}{ Parameter } & \multicolumn{1}{c}{ Ventilation shaft } & \multicolumn{1}{c}{ Exploration borehole } \\
\hline Aquifer saturated thickness & $450 \mathrm{ft}$ & $450 \mathrm{ft}$ \\
Observation well opening & From 190 to $390 \mathrm{ft}$ & From 190 to $390 \mathrm{ft}$ \\
Distance to pumping well & $775 \mathrm{ft}$ & $40 \mathrm{ft}$ \\
Pumping well & Fully penetrating & Fully penetrating \\
Pumping well casing radius & $2 \mathrm{ft}$ & $0.25 \mathrm{ft}$ \\
Effective pumping well radius & $2 \mathrm{ft}$ & $0.25 \mathrm{ft}$ \\
Aquifer type & Unconfined & Unconfined \\
& \multicolumn{1}{c}{ Estimated } & \\
Aquifer & Isotropic & Isotropic \\
Transmissivity & 0.006 to $0.0009 \mathrm{ft}^{2} / \mathrm{s}$ & 0.006 to $0.0009 \mathrm{ft}^{2} / \mathrm{s}$ \\
Storage coefficient & 0.01 to 0.30 & 0.01 to 0.30 \\
Pumping rate & 0.2 to $2.5 \mathrm{ft}^{3} / \mathrm{s}$ & No determination \\
\hline
\end{tabular}

The transmissivity values were unknown but estimates were calculated from hydraulic conductivity values for the Ozark aquifer reported by Imes and Emmett (1994) for their regional ground-water study of the Ozark Plateaus aquifer system and from Steffen Robertson and Kirsten, Inc. (1988) while performing aquifer testing in Bixby wells. Data from these two sources were used to estimate the upper [0.006 square foot per second, $\left.\left(\mathrm{ft}^{2} / \mathrm{s}\right)\right]$ and lower $\left(0.0009 \mathrm{ft}^{2} / \mathrm{s}\right)$ transmissivity limits for the analysis. The storage coefficient value was assigned "text book" limits for unconfined aquifers ranging from 0.01 to 0.30 (Freeze and Cherry, 1979). The start time at which the discharge began was also unknown and was varied from 0 to 250 days before the drawdown was first observed in well VT-4. No solution could be achieved when using a discharge start time beyond 250 days and the predefined limits for the transmissivity and storage coefficient.

There are an infinite number of solutions to the analysis because of the various unknown parameters; consequently, a range of discharge values was determined. During the analysis, a discharge start time was assigned. The discharge rate was then varied and the Theis type curve was adjusted to determine if the discharge rate and start time combination was possible for the resulting drawdown data and the predefined limits for the transmissivity and storage coefficient. The steady-state conditions that occurred after the drawdown (fig. $6 \mathrm{D})$ could be the result of a boundary condition that was encountered at a farther distance from the ventilation shaft than well VT-4, or perhaps leakage (recharge) into the aquifer. For this cursory analysis, the standard Theis approach is considered appropriate to estimate possible water discharge rates from the aquifer.
The analysis indicated that the discharge needed to cause the observed drawdown in well VT-4 ranged from 0.2 to 2.5 cubic foot per second (90 to about 1,120 gallons per minute) in the ventilation shaft scenario. A solution could not be achieved using the exploration borehole scenario and the predefined limits for the transmissivity and storage coefficient; therefore, no discharge was estimated for this scenario.

In addition to monitoring the Ozark aquifer over active mining areas, another aspect of this study was to observe waterlevel responses in areas where the initial geohydrologic conditions at a well might change during the study. Well VT-1 was placed over a closed mine that was allowed to start flooding in August 2004. If mine dewatering had affected the Ozark aquifer in this area, a water-level increase in the aquifer near the mine would be a reasonable expectation after the mine floods. After the mine fills with water and the water level reaches the top of the St. Francois aquifer (base of the St. Francois confining unit), a pressure head would develop in the St. Francois aquifer. As the pressure head increases, the hydraulic gradient between the Ozark aquifer and the St. Francois aquifer would decrease. If the pressure head in the St. Francois aquifer would meet or exceed the water level in the Ozark aquifer, this increased head in the St. Francois aquifer could increase water levels in the Ozark aquifer by either reducing downward leakage or inducing an upward flow of water into the Ozark aquifer. The hydrograph for VT-1 (fig. 6A) does not indicate that water levels were consistently higher immediately after the August 2004 mine closure. The water-level trough that occurred in fall 2004, and the subsequent recovery period that occurred during winter and spring of 2005, were similar to the corresponding features of the preceding years and reflect seasonal water-level fluctuations. 


\section{Ground-Water Levels in the Ozark Aquifer along the Viburnum Trend, Southeastern Missouri, 2001-05}

The annual trough that developed in fall 2005 is not as well defined, and is about 4 feet higher than any previous recorded trough observed in well VT-1 during the study. The current status of the mine flooding is unknown; however, it may be several years before a pressure head develops in the St. Francois aquifer at well VT-1. Another explanation for the high water-level trough in fall 2005 is the greater than normal amount of precipitation that occurred in the area (fig. 5) during September 2005. Water levels in the deeper wells (VT-2, VT-5, and VT-6) also follow a similar pattern of increasing water-level trough altitudes with time.

Wells VT-5 and VT-8 were placed in front of mine workings with the expectation of the mine eventually reaching the area beneath the well sites. If mine dewatering was going to affect water levels in the Ozark aquifer in these areas and cause continuous large-scale drawdown, it is expected that waterlevel declines in the Ozark aquifer would occur after mine workings arrive beneath the wells. Consequently, water levels would continue to decline annually below the previously observed lowest values of each preceding year. In plan view, the mine workings have presently (2006) approached within 110 feet of well VT-5 and 10 feet of well VT-8 (Denis Murphy, The Doe Run Company, written commun., 2006). The vertical distance between the bottom of the wells and mines is measured in many hundreds of feet. The hydrograph for well VT-5 shows no indication of continuous drawdown occurring as a result of mine dewatering in the vicinity of the well. The hydrograph instead shows that the base of the water-level trough each year is consistently higher than the previous year. The hydrograph for well VT-8, however, does show a lowering of the waterlevel trough in 2004 and 2005. This is the expected response if mining has reached the well site and mine dewatering was affecting water levels in the well.

Wells VT-1 and VT-8 are the shallowest wells in the network and have similar construction (table 1). The water levels in the two wells generally responded similarly and maintained a consistent amount of separation during the first 2 years of the study but this appears to have changed in 2004 (fig. 6A). To investigate this, the water-level difference at the two wells was calculated by subtracting the daily mean water level for well VT-8 from well VT-1 (fig. 7A). The data show the water-level difference between the two wells has converged from over 20 feet to less than 5 feet, during the 4 years of the study.

It is unknown if the converging water levels in wells VT-1 and VT-8 are a natural ground-water response to local precipitation in the vicinity of the wells or mining induced. If mining induced, the convergence can be explained by the rising water levels in well VT-1 as the mine beneath it floods and the falling water levels in well VT-8 as mine dewatering begins beneath the well. Because of the short lag time between precipitation events and water-level responses in these two wells (fig. 6A), the correlation between water-level response and precipitation at these two wells can be investigated.

No usable precipitation data were available in the vicinity of either well VT-1 or VT-8, so precipitation data for the period 2002 through 2005 were tabulated from NOAA reporting cli- matological stations in Bunker, Ellington, Round Spring, Salem, and Steelville (figs. 1 and 8). These climatological stations were chosen based on their proximity and spatial distribution in relation to the monitoring wells. It is assumed the estimated monthly precipitation totals calculated from the available precipitation data is the amount that occurred at each well. The estimated monthly precipitation occurring at well VT-1 was calculated by averaging the daily precipitation values at Bunker, Salem, and Steelville and then adding the average daily values for each month. The estimated monthly precipitation for well VT-8 was calculated using the same technique as well VT1 but with climatological data reported for Bunker, Ellington, and Round Spring. During 2002 through 2005, it was estimated well VT-1 received 183.6 inches of precipitation and well VT8 received 186.0 inches (National Oceanic and Atmospheric Administration, 2002-2005). This 2.4-inch difference is not considered significant over a 4-year period, and these precipitation totals do not explain the decreasing water-level difference observed between well VT-1 and well VT-8.

The monthly precipitation difference and the daily mean water-level difference between wells VT-1 and VT-8 also were compared to determine if a correlation exists between these two parameters. The monthly precipitation difference at the two well sites was calculated by subtracting the monthly totals determined for well VT-1 from the corresponding monthly totals determined for well VT-8 (fig. 7B). When a positive number was calculated (greater monthly rainfall at well VT-8), the water level at well VT-8 would be expected to rise more than the water level at well VT-1 where the rainfall was less. Therefore, the water-level difference between the wells would be expected to increase. Conversely, when a negative monthly precipitation difference was calculated, the water-level difference would be expected to decrease.

The results of the comparison between monthly precipitation and water-level differences indicate a correlation may exist for most of the period 2002 through 2005. During 2002 through June 2003, well VT-8 received about 5 inches less precipitation than well VT-1 (fig. 7B and C) and the water-level difference between these wells shows a slightly decreasing trend. In February 2002, when the study began, the water-level difference was about 25 feet and by June 2003 this difference decreased to less than 20 feet. This is the anticipated water-level response if local precipitation was the cause for the water-level convergence.

During the period July through December 2003, conditions changed and well VT- 8 received about 7 inches more precipitation than well VT-1. This excess rainfall at well VT-8 not only halted the downward trend in water-level difference between the two wells, but reversed the trend and the waterlevel difference increased during this period. This also was the expected response if local precipitation was controlling waterlevel changes.

From January through June 2004, another transition occurs in the mean daily water-level difference. The water-level difference decreased from about 25 feet to about 10 feet. During this same period, there was no significant overall precipitation dif- 

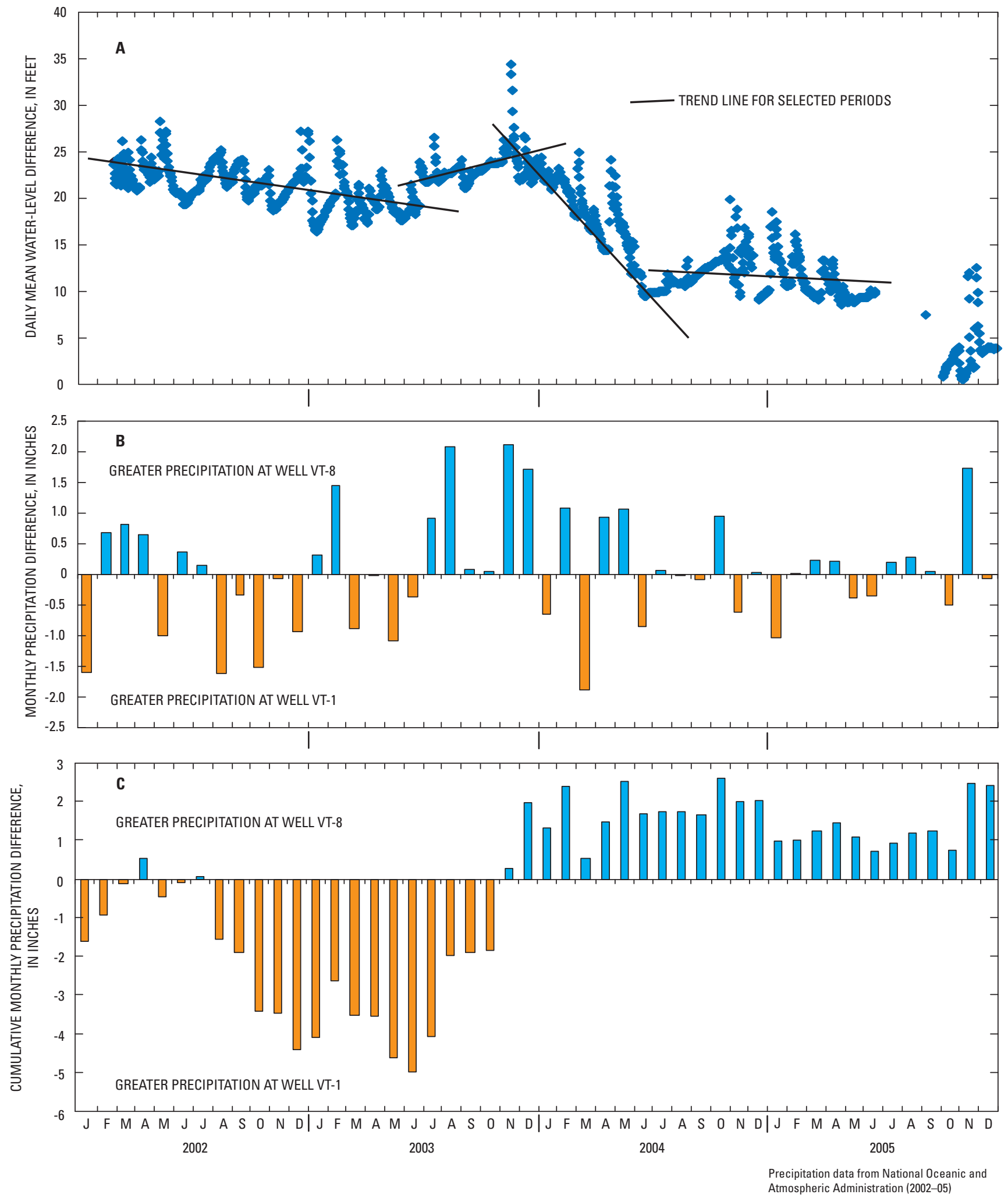

Figure 7. Difference between (A) daily mean water levels (VT-1 minus VT-8), (B) monthly precipitation, and (C) cumulative monthly precipitation at wells VT-1 and VT-8, 2002 through 2005. 


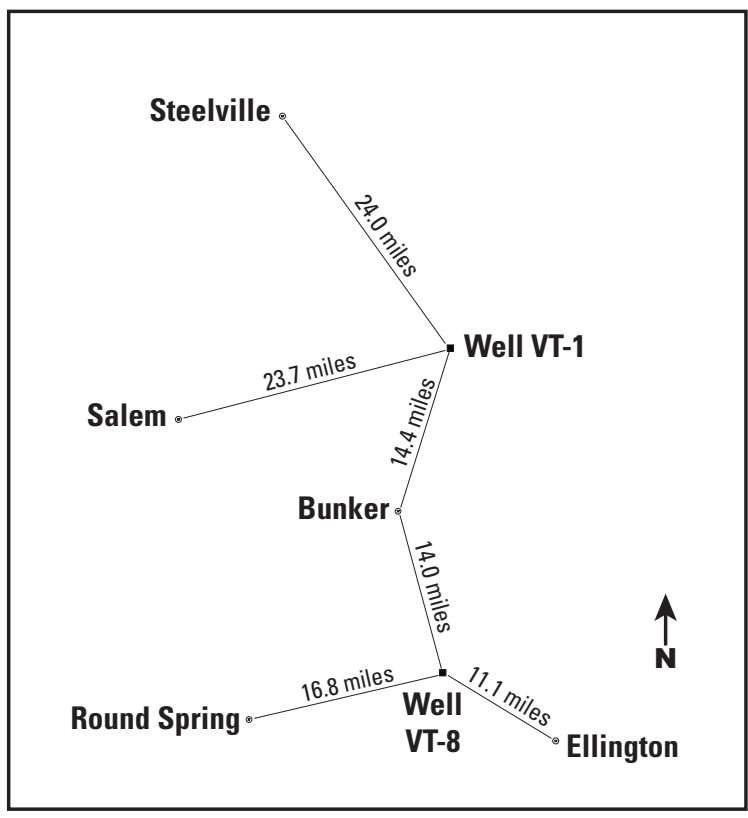

Figure 8. Schematic diagram of well VT-1, well VT-8, and climatological station locations.

ference at the two wells; consequently, precipitation differences do not appear to be the cause for the decreasing water-level difference during this period.

From June 2004 to June 2005, there was no substantial precipitation difference at the two wells. As expected, if local precipitation was controlling water-level changes, the water-level difference between the two wells generally remained between 10 to 15 feet. At the end of June 2005, there was an interruption in data collection at well VT-8. When data collection resumed at the well in October 2005, the water-level difference between the two wells had decreased to less than 5 feet with no corresponding precipitation difference to explain the sudden decrease.

The water-level data from October through December 2005 have considerable scatter, but over this short period there appears to be an upward trend in the water-level difference. Well VT- 8 received about 1 inch more precipitation than well VT-1 (fig. 7C) during this period, and the result was that the waterlevel difference between the wells increased. This is the expected response if local precipitation were controlling the water-level changes.

It is concluded that for most of the period from 2002 to 2005, the converging water-level difference that occurred at wells VT-1 and VT- 8 is a result of local precipitation differences rather than being mining induced. However, local precipitation differences do not explain the 15-foot decrease in water-level difference that was observed during the period January through June 2004.

\section{Summary and Conclusions}

During 2001, eight monitoring wells were installed in a generally linear pattern along the Viburnum Trend to determine if dewatering in the lead-zinc mines in the St. Francois aquifer has affected water levels in the surficial Ozark aquifer. The well locations were chosen specifically to be in areas where mining was scheduled to cease and mine flooding would occur, in areas where mine workings were progressing toward and would be occurring after well installation, or directly over active mining areas. Typically, the wells were drilled to less than 100 feet below the top of the water table.

Before data collection, much of southern Missouri, including the Viburnum Trend area, experienced a drought that began in late 1999. Dry conditions existed in the area until early 2002, about the time when the wells were equipped with water-level recorders. This dry period culminated during the spring and summer of 2001, when the cumulative precipitation from 1996 to 2001 was more than 11 inches below normal in the East Ozarks region.

The water-level data indicate no long-term, continuous water-level declines occurred from 2002 to 2005 at five monitoring wells, four of which are over active mining areas. Conversely, these five wells (VT-2, VT-3, VT-5, VT-6, and VT-7) had increasing water levels with time. On a local scale, however, the water-level data reinforces conclusions of previous investigations that state small areas of drawdown in the Ozark aquifer may be present along the Viburnum Trend as a result of mine dewatering. A long-term water-level decline of about 30 foot that developed during the study at monitoring well VT-4, which also is over an active mining area, indicates an isolated area of drawdown in the Ozark aquifer. While the cause of the water-level decline is unknown, it is hypothesized that the drawdown was caused by a change in subsurface hydraulic characteristics of the Ozark aquifer or the underlying St. Francois confining unit in the vicinity of the well. This allowed additional ground-water flow, either diffuse or discrete, to occur from the Ozark aquifer. It also is hypothesized that water may be moving from the Ozark aquifer into the mine workings in the St. Francois aquifer in the vicinity of the well through either a former exploration borehole that was plugged and abandoned, or a nearby mine ventilation shaft. Because these same type auxiliary structures are present at other monitoring well locations where no water-level declines were observed, the presence of these structures does not necessarily infer that water-level declines will occur or are occurring near all these type structures.

Well VT-1 is over an abandoned mine that is being allowed to flood. During 2005, water levels in this well showed an upward trend. Wells VT-5 and VT-8 were placed in areas where mining was expected to occur after the start of the study. In plan view, the mine workings have presently (2006) approached within 110 feet of well VT-5 and 10 feet of well VT-8. The vertical distance between the wells and mines is measured in many hundreds of feet. The hydrograph for well VT-5 shows no indication that continuous water-level declines are occurring. The hydrograph for well VT-8, however, shows a lowering of the ground-water trough in 2004 and 2005.

It was investigated whether the water-level response in these two wells is a natural ground-water response to local precipitation in the vicinity of the wells as opposed to being mining induced. Comparing monthly precipitation and daily mean 
water-levels differences at these two wells indicates that for most of the period from 2002 to 2005 , the converging waterlevel difference that occurred can be explained by local precipitation differences rather than being mining induced. Local precipitation differences, however, do not explain the 15-foot decrease in water-level difference that was observed during the period January through June 2004.

\section{References}

Fletcher, C.S., 1974, The geology and hydrogeology of the New Lead Belt, Missouri: University of Missouri-Rolla, unpublished M.S. thesis, 91 p.

Freeze, R.A., and Cherry, J.A., 1979, Groundwater: PrenticeHall, Inc., Englewood Cliffs, New Jersey, 604 p.

Hauck, H.S., and Harris, T.E., 2006, Water resources data, Missouri water year 2005: U.S. Geological Survey Water-Data Report MO-05-1, 724 p. (published annually), CD-ROM.

Hauck, H.S., and Nagel, C.D., 2003, Water resources data, Missouri, water year 2002: U.S. Geological Survey Water-Data Report MO-02-1, 567 p. (published annually), CD-ROM.

Hauck, H.S., and Nagel, C.D., 2004, Water resources data, Missouri, water year 2003: U.S. Geological Survey Water-Data Report MO-03-1, 776 p. (published annually), CD-ROM.

Hauck, H.S., and Nagel, C.D., 2005, Water resources data, Missouri, water year 2004: U.S. Geological Survey Water-Data Report MO-04-1, 798 p. (published annually), CD-ROM.

Imes, J.L., and Emmett, L.F., 1994, Geohydrology of the Ozark Plateaus aquifer system in parts of Missouri, Arkansas, Oklahoma, and Kansas: U.S. Geological Survey Professional Paper 1414-D, $127 \mathrm{p}$.

Kleeschulte, M.J., 2001, Effects of lead-zinc mining on groundwater levels in the Ozark aquifer in the Viburnum Trend, Southeastern Missouri: U.S. Geological Survey WaterResources Investigations Report 00-4293, 28 p.

Middendorf, M.A., and others, 2003, Geologic Map of Missouri: Rolla, Missouri, Missouri Department of Natural Resources, Missouri Geological Survey, 1 sheet.

Miller, D.E., and Vandike, J.E., 1997, Groundwater resources of Missouri: Water Resources Report Number 46, Missouri State Water Plan Series, Vol. II, Rolla, Missouri, Missouri Department of Natural Resources, Division of Geology and Land Survey, $210 \mathrm{p}$.

National Oceanic and Atmospheric Administration, 1996-2005, Climatological data annual summary, Missouri: Asheville, North Carolina, National Climatic Center, v. 100-109, no. 13 .

National Oceanic and Atmospheric Administration, 2002-2005, Climatological data monthly, Missouri: Asheville, North Carolina, National Climatic Center, v. 106-109, no. 1-12.

Steffen Robertson and Kirsten, Inc., 1988, Results of phase I groundwater investigation, Bixby, Missouri: Lakewood, Colorado, $35 \mathrm{p}$.
University of Missouri-Columbia, 2006, University of Missouri Information: accessed June 28, 2006, at URL http:/ /www.drought.unl.edu/dm/archive/99/drmon0928.htm

Wharton, H.M., 1975, Introduction to the southeast Missouri lead district, in Vineyard, J.D., ed., The geology and ore deposits of selected mines, Viburnum Trend, Missouri: Division of Geology and Land Survey, Report of Investigations 58, p. 3-14.

Warner, D.L., Fletcher, C.S., and Cesare, J.A., 1974, Effect of mining operations on ground water levels in the New Lead Belt, Missouri: Rolla, Missouri, University of MissouriRolla, Project Number A-060-MO, 86 p. 
Table 
Table 2. Manually measured water levels in Viburnum Trend monitoring wells, 2001 through 2005.

[All water levels are depth-to-water in feet below land surface; --, no data; maximum measured water level for well is in box; minimum water level for well is bold type]

\begin{tabular}{|c|c|c|c|c|c|c|c|c|}
\hline & Well VT-1 & Well VT-2 & Well VT-3 & Well VT-4 & Well VT-5 & Well VT-6 & Well VT-7 & Well VT-8 \\
\hline Date & Water level & Water level & Water level & Water level & Water level & Water level & Water level & Water level \\
\hline $10 / 31 / 2001$ & -- & -- & -- & -- & -- & -- & 142.31 & -- \\
\hline $11 / 19 / 2001$ & -- & -- & -- & -- & -- & 143.59 & 142.38 & 50.93 \\
\hline $11 / 26 / 2001$ & -- & -- & -- & -- & -- & 143.73 & 142.42 & 51.11 \\
\hline $12 / 04 / 2001$ & -- & -- & -- & -- & 137.54 & -- & -- & -- \\
\hline $12 / 13 / 2001$ & 70.28 & 291.29 & 117.56 & -- & -- & -- & -- & -- \\
\hline $12 / 14 / 2001$ & 70.05 & 285.28 & 117.56 & 358.14 & 137.95 & 143.84 & 142.60 & 51.00 \\
\hline 01/15/2002 & -- & -- & 118.39 & -- & -- & -- & -- & -- \\
\hline 01/16/2002 & -- & -- & -- & -- & 137.81 & 143.26 & 142.69 & 48.97 \\
\hline 01/17/2002 & 68.15 & 274.52 & -- & -- & -- & -- & -- & -- \\
\hline $02 / 12 / 2002$ & 65.06 & 273.38 & -- & -- & -- & -- & -- & -- \\
\hline $02 / 13 / 2002$ & 65.57 & 273.44 & 119.04 & 360.59 & -- & 141.61 & -- & -- \\
\hline $02 / 21 / 2002$ & 66.12 & 272.65 & 118.88 & 359.54 & 136.96 & -- & -- & -- \\
\hline $02 / 22 / 2002$ & -- & -- & -- & -- & 137.06 & -- & 142.97 & 41.39 \\
\hline 03/07/2002 & 64.54 & 272.38 & 118.94 & 359.84 & 136.54 & 140.78 & 142.60 & 42.76 \\
\hline 03/19/2002 & -- & -- & -- & -- & -- & -- & 142.06 & -- \\
\hline 04/29/2002 & 56.39 & 258.72 & -- & -- & -- & -- & -- & -- \\
\hline 05/06/2002 & -- & -- & 115.75 & 359.00 & 130.20 & 130.95 & -- & -- \\
\hline 05/07/2002 & -- & -- & -- & -- & -- & -- & 140.81 & 33.91 \\
\hline 07/15/2002 & 62.10 & 243.29 & 112.83 & 356.19 & 127.55 & 128.59 & 139.56 & 40.69 \\
\hline $07 / 22 / 2002$ & -- & -- & -- & -- & -- & -- & -- & 40.91 \\
\hline 09/10/2002 & 65.80 & 247.08 & 114.35 & 353.54 & 128.87 & 132.42 & 139.74 & 41.99 \\
\hline $11 / 14 / 2002$ & 67.61 & 252.55 & 116.47 & 352.34 & 130.79 & 135.51 & 140.48 & 48.26 \\
\hline 01/17/2003 & 64.53 & 257.24 & 118.50 & 356.44 & 131.16 & 137.65 & 141.46 & 47.42 \\
\hline $02 / 12 / 2003$ & 69.70 & 258.24 & 118.89 & 363.74 & 131.56 & 138.45 & 141.91 & 49.21 \\
\hline 03/14/2003 & 61.45 & 256.87 & 118.50 & 369.04 & 130.39 & 137.70 & 141.63 & 43.33 \\
\hline $04 / 18 / 2003$ & 59.63 & 253.66 & 117.14 & 372.77 & 129.48 & 136.16 & 141.21 & 40.91 \\
\hline $05 / 21 / 2003$ & 58.41 & 250.75 & 115.71 & 377.54 & 127.58 & 134.14 & 140.83 & 40.11 \\
\hline 06/06/2003 & -- & -- & -- & 377.09 & -- & -- & -- & -- \\
\hline
\end{tabular}


[All water levels are depth-to-water in feet below land surface; --, no data; maximum measured water level for well is in box; minimum water level for well is bold type]

\begin{tabular}{|c|c|c|c|c|c|c|c|c|}
\hline & Well VT-1 & Well VT-2 & Well VT-3 & Well VT-4 & Well VT-5 & Well VT-6 & Well VT-7 & Well VT-8 \\
\hline Date & Water level & Water level & Water level & Water level & Water level & Water level & Water level & Water level \\
\hline $06 / 17 / 2003$ & 58.64 & 248.95 & 114.88 & 378.59 & 127.41 & 133.16 & 140.36 & 40.23 \\
\hline $07 / 18 / 2003$ & 64.41 & 249.07 & 114.93 & 379.61 & 127.85 & 133.69 & 140.44 & 42.22 \\
\hline 08/13/2003 & 65.93 & 250.08 & 115.53 & 380.66 & 128.22 & 133.80 & 140.38 & 43.19 \\
\hline $09 / 12 / 2003$ & 66.40 & 251.30 & 115.96 & 379.14 & 128.70 & 134.49 & 140.24 & 44.77 \\
\hline $09 / 25 / 2003$ & -- & -- & -- & -- & 129.31 & 135.20 & 140.64 & 45.67 \\
\hline $10 / 14 / 2003$ & 70.89 & 253.45 & 116.79 & 378.18 & -- & -- & -- & -- \\
\hline $10 / 27 / 2003$ & -- & -- & -- & -- & 130.58 & 136.16 & 140.77 & 47.87 \\
\hline $11 / 14 / 2003$ & 73.20 & 257.15 & 118.13 & 381.39 & 130.77 & 137.07 & 141.18 & 48.36 \\
\hline 01/06/2004 & 60.56 & 257.71 & 119.04 & 382.66 & 128.68 & 133.67 & 141.06 & 36.77 \\
\hline 01/08/2004 & -- & -- & -- & 381.15 & -- & -- & -- & -- \\
\hline 03/03/2004 & 63.37 & 254.63 & 117.02 & 381.09 & 127.40 & 131.97 & 139.91 & 45.35 \\
\hline $04 / 22 / 2004$ & -- & -- & -- & 378.95 & 126.00 & 130.29 & 138.97 & 47.32 \\
\hline 05/18/2004 & 58.87 & 249.57 & 114.45 & 380.85 & 124.33 & 127.39 & 138.51 & 42.77 \\
\hline 06/08/2004 & 60.52 & 248.35 & 114.19 & 381.06 & 124.42 & 127.83 & 138.23 & 48.46 \\
\hline $07 / 15 / 2004$ & 64.62 & 248.25 & 114.55 & 380.20 & 125.07 & 129.62 & 138.01 & 54.65 \\
\hline 09/01/2004 & 69.96 & 250.77 & 116.00 & 381.88 & 126.60 & 132.15 & 138.21 & 58.91 \\
\hline $09 / 02 / 2004$ & -- & 250.45 & -- & -- & -- & -- & -- & -- \\
\hline 09/13/2004 & -- & 251.21 & -- & -- & -- & -- & -- & -- \\
\hline $10 / 05 / 2004$ & -- & -- & -- & -- & -- & -- & -- & 60.45 \\
\hline $10 / 18 / 2004$ & 74.02 & 252.95 & 116.71 & 378.36 & 127.57 & 133.33 & 138.27 & -- \\
\hline $12 / 08 / 2004$ & 59.21 & 253.67 & 118.24 & 380.19 & 126.64 & 132.14 & 138.21 & 45.29 \\
\hline $12 / 13 / 2004$ & -- & -- & -- & -- & -- & -- & 138.30 & -- \\
\hline $12 / 16 / 2004$ & 59.27 & -- & 118.34 & -- & -- & -- & 138.03 & -- \\
\hline $01 / 17 / 2005$ & 57.46 & 251.27 & 118.13 & 383.34 & 125.57 & 129.74 & 137.87 & 43.45 \\
\hline $01 / 21 / 2005$ & -- & 249.01 & -- & 378.18 & -- & -- & -- & -- \\
\hline $02 / 15 / 2005$ & 58.77 & 246.94 & 115.93 & 378.02 & 124.18 & 127.74 & 136.90 & 43.54 \\
\hline 03/18/2005 & -- & -- & -- & -- & -- & -- & 136.87 & 50.11 \\
\hline $03 / 29 / 2005$ & 58.24 & 244.65 & 114.72 & 378.53 & 124.08 & 126.94 & -- & -- \\
\hline 05/04/2005 & 56.23 & 243.74 & 114.63 & 382.01 & 123.72 & 126.50 & 136.90 & 46.84 \\
\hline
\end{tabular}


Table 2. Manually measured water levels in Viburnum Trend monitoring wells, 2001 through 2005.-Continued

[All water levels are depth-to-water in feet below land surface; --, no data; maximum measured water level for well is in box; minimum water level for well is bold type]

\begin{tabular}{|c|c|c|c|c|c|c|c|c|}
\hline & Well VT-1 & Well VT-2 & Well VT-3 & Well VT-4 & Well VT-5 & Well VT-6 & Well VT-7 & Well VT-8 \\
\hline Date & Water level & Water level & Water level & Water level & Water level & Water level & Water level & Water level \\
\hline $06 / 21 / 2005$ & 63.05 & 243.43 & 114.79 & 381.95 & 124.31 & 127.67 & 137.19 & 53.18 \\
\hline 09/08/2005 & 67.53 & 246.31 & 116.88 & 381.52 & 125.69 & 130.39 & 138.38 & 60.08 \\
\hline $10 / 05 / 205$ & -- & -- & -- & -- & -- & -- & -- & 60.45 \\
\hline $10 / 13 / 2005$ & 63.11 & 247.98 & 117.68 & 380.91 & 126.27 & 131.16 & 139.03 & 61.14 \\
\hline $12 / 01 / 2005$ & 59.42 & 249.93 & 118.35 & 380.62 & 125.54 & 130.52 & 139.70 & 50.35 \\
\hline Minimum & 56.23 & 243.29 & 112.83 & 352.34 & 123.72 & 126.50 & 136.87 & 33.91 \\
\hline Maximum & 74.02 & 291.29 & 119.04 & 383.34 & 137.95 & 143.84 & 142.97 & 61.14 \\
\hline Fluctuation & 17.79 & 48.00 & 6.21 & 31.00 & 14.23 & 17.34 & 6.10 & 27.23 \\
\hline
\end{tabular}


